\title{
THE UNIVERSITY COLLEGE
}

\section{AT BUCKINGHAM, ENGLAND}

\author{
BY JOHN E. PEMBERTON
}

Mr. Pemberton is librarian at the University College at Buckingham

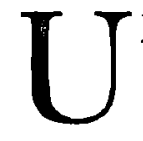

NTIL the advent of the University College at Buckingham Britain had not witnessed the creation of a privately-financed University institution for more than half a century. Moreover, those which earlier had been founded by private initiative were now no longer independent of State finance. In 1938-39 the public purse was providing 45 per cent of the total income of Universities, by $1967-68$ the proportion had increased to 75 per cent, and by the time of the foundation of UCB it had risen to 90 per cent. With the single exception of this new College, all the new Universities established in Britain in the postwar years have been within the public sector. In the words of its Principal, Professor Max Beloff, the University College at Buckingham therefore 'runs counter to the accepted orthodoxy according to which the State should be the only provider of education and all provision outside the public domain should be regarded as a transient exception to the rule.' In this one can see two major complementary propositions concerning the philosophy which underlies this new project and the tenets which guide its implementation in the real world of buildings, facilities, teachers and students. UCB has been established as an academic community in which the pursuit of scholarly excellence is untrammelled by the dictates of dirigisme, and an institution which provides a permanent alternative to the State system for those who prefer to avoid the inhibitions of normative policies.

What inspired its progenitors was the belief that for new initiatives to flourish, new ideas to be nurtured, new theories to be tested in the constant endeavour to match the educational process to the needs of society a new and independent University would offer many advantages. And these advantages would commend themselves to many interests, thus ensuring that such an institution would receive the continuous material support of benefactors, the intellectual stimulus of like-minded academics throughout the world, and the enthusiastic participation of professors and students in the College's daily life. 
Such aspirations could lightly be dismissed as the illusory ambitions of idealists, born in a momentary euphoria of visionary ardour. History, however, provides the contradiction: the gestatory period lasted several years during which the resilience of the embryo was tested by crises of one sort or another; it survived the strains of organic growth and eventually took on sufficient shape and substance to be recognisable as a functioning organism.

On February 6, I976 Mrs. Margaret Thatcher, former Secretary of State for Education, gave the inaugural address at the opening ceremony before a gathering which included the first intake of seventy students. She spoke of the College as 'a practical experiment in thinking out in contemporary terms what is essential to education by contrast with what we have merely become accustomed to enjoy.' UCB is now one year old and a further one hundred students have arrived to begin their studies. It is therefore an appropriate moment at which to pause and reflect on the differences they may unknowingly encounter from the situation which confronted their pioneering predecessors twelve months previously.

Rather like the second party to land on the moon, the most obvious difference the new students will realise is that others have been there before-indeed are still there. An infrastructure of organised student life already exists, though there still remains a good deal of scope for the new arrivals to influence the shape of things, to add to the range of societies, to help create the precedents and conventions by which future generations of students will inevitably feel bound. It is likely that their seniors may feel a sense of relief that they can now share the load, though there were few signs that the challenge of creating the organs of corporate student activity while undertaking a strenuous academic programme caused any real problems of stress. After the election of a President and representative officers, the Student Union embarked on a remarkably full calendar of social, sporting and cultural events. Now, in their second year, these same students will be preparing for their final examinationsthe structure of the academic year will be described later-and it would be reasonable to suppose that they will be pleased to pass on the baton.

In one respect students of both years will share a common experience. They are more diverse in their backgrounds-both as regards age and nationality - than is usual in an undergraduate college. 
Their ages range from eighteen to forty-eight, and close to one third come from overseas-from continental Europe, Asia, Africa, Australia, and North America. In addition to the full two-year students there are a number of American students who come to Buckingham to study either for their junior year in Europe or for a single semester. Whilst welcoming, and indeed encouraging, this international dimension, the College is and will remain an essentially British institution; and it will continue to seek the benefits which can flow from a blend of youth and maturity. It is the College's stated policy that no student will be excluded on grounds of race, colour, creed, or political beliefs; and the first year's experience has already shown the degree of vigour and harmony that can be attained in a community whose common aim is the pursuit of knowledge and which, most importantly, is of a size and character which allows students, staff and faculty to develop a proper human acquaintance.

There is little in the outward physical appearance of the College that has changed since the first students arrived, though a good deal has changed inside. Many of the buildings which comprise the nucleus of the campus, pleasantly situated within a loop of the River Ouse, date from the eighteenth and early nineteenth centuries. Architectural interest therefore precludes modification of their exteriors, but considerable internal alteration has been carried out to fit them for their new purpose. In the past year this work has been completed, providing additional teaching areas, doubling the Library space and creating further common-room facilities.

When one comes to consider purely academic matters, the developments which have taken place have on the one hand been predictable advances along paths already entered upon, and on the other adjustments of course made in response to problems encountered in translating theoretical aims into practical experience. To the three original Schools of Study (Law; Economics; and Law, Economics and Politics) has been added a fourth (History, Politics, and English Literature), and a fifth (European Studies) is at an advanced stage of preparation. The special French Language course arranged in association with the Free University of Lille (and taught there) has been complemented by a course in German at the University of Saarbrücken. These courses are taken by students before they begin their two-year degree programme in Buckingham, and are offered as a facility for those who might otherwise have difficulty in meeting 
the College's requirement that all its graduates should have a reading knowledge of two foreign languages. Language teaching is also given at the College, including language laboratory instruction. It is in the language area, namely in the ability of certain overseas students to follow the subject tuition given in English, that one adjustment has had to be made. Intensive courses in English as a foreign language were introduced during the course of the first year and have proved to be of immense benefit.

A range of supporting courses, which includes those in languages, aims to provide a breadth of education and so enable students to avoid the overspecialisation which has been a cause for criticism of so many University curricula. Buckingham undergraduates are required to provide evidence of being numerate as well as literate and to this end undertake supporting courses either in mathematics or the life sciences. Experience in the first year showed a natural tendency among students to neglect these ancillary studies in favour of their principal subjects, and it was found necessary both to define the level of achievement that was required and at the same time to emphasize that granting of the degree was dependent on their reaching that level. A course in library studies, though not examined, is compulsory for all students and is given their first term.

Understandably the progress of UCB continues to be watched with interest by those in Britain and abroad who have become concerned about the financing of higher education and who see the logic in restructuring the academic year so as to allow a student to graduate after two full years of study. By eliminating the long summer vacation and fitting four ten-week terms into the academic year (which begins in February), it is certainly possible to provide a sufficient amount of teaching. But that teaching needs to be of a particular kind and to be carried on in a special environment. The very fact that the town of Buckingham is small and compact means that whether students live in College properties or find lodgings elsewhere they have a real sense of community-not only among themselves but with the faculty as well. This is reinforced by the teaching which takes the form largely of seminars and tutorials and allows a close personal relationship between teacher and taught to be established. It is selfevident that the system makes considerable demands on both parties, but the belief of the College founders in the motivations of those who take a responsible attitude towards the benefits of higher educa- 
tion, both to themselves and to the society in which they live, bids fair to find its reward. Final justification will, however, have to await the results of the examiners at the end of 1977 .

It will not be difficult to judge the performance of Buckingham students. Both intermediate and final papers are marked by external as well as internal examiners, and the former have been advised that they are expected to apply the same standards in Buckingham as they do in their own Universities. In order to ensure the best possible conditions for success the College has been at pains always to seek the advice of distinguished academics in such matters as curriculum design, faculty appointments and teaching methods. In particular it is able to consult its Academic Advisory Council and International Advisory Council, whose memberships consist of acknowledged leaders in the various subjects embraced by the syllabuses.

At a joint meeting in April 1976 these two councils adopted a resolution to the effect that the approval given to the Buckingham Licence by the legal and other professional bodies, its recognition by other Universities as a prima facie qualification for admission to postgraduate work on terms of equality with first degrees from other institutions, and the spontaneous public announcements by major employers of its acceptance by them, constituted an unequivocal guarantee to students of the value of the qualification they would earn. At the appropriate time the College intends to petition for a Royal Charter, the instrument by which authority to confer degrees of Bachelor, Master and Doctor is conventionally acquired by British Universities. The view has however been expressed that the distinctive appellation of the Buckingham Licence may well survive as the title of the College's first degree.

Looking to the more immediate future the 1977 entrants will benefit from conditions which their fellows of the previous year have helped to create. Student representatives on the Library Committee, for example, have participated in discussions relating to such matters as the provision of multiple copies of course texts, student helps, and opening hours; while those on the Domestic Committee have contributed to decision-making regarding refectory meals, commonroom facilities and housing regulations. Students are also represented on the Regulations and Conduct Committee and have the right of direct access to the Senate should cases of major concern to 
the students arise. At the first General Assembly, held in December I 976, almost the entire student body attended in order to hear the Principal's report on the first year's work and to put questions publicly both to the Principal and to other College officers.

Extra-mural relations - those between Town and Gown-are formalized through a Local Liaison Committee which was originally set up spontaneously by representatives of the local community, under the chairmanship of a former Mayor of Buckingham, to explore ways in which the townspeople could assist the College. It now includes UCB representatives and has been instrumental in promoting joint activities of which a series of Buckingham Lectures, sponsored by the College but open to interested members of the public, is a typical example. There are in addition many less formal links notably with cultural, recreational and sporting societies, and with nearby Stowe School-one of Britain's major public (i.e. private) schools-which has made its sports facilities available and invites College members to its musical and other events.

Support by the people of Buckingham and the adjacent counties has also manifested itself in membership of the Friends of the University College at Buckingham, an association, having its office in the College, whose principle aim is to provide funds for facilities which it might otherwise be difficult to finance. In this it differs from the work of the College's own Endowment Office which is concerned with raising further capital to enable the College to extend the range of its courses, to acquire and equip the necessary buildings, and to solicit the endowment of scholarships and bursaries. The foundation capital came from a number of sources-private individuals, industrial and commercial companies, trusts and foundations-and new benefactions received during the first year of operations have meant that there has been no interruption in implementing the developments already planned. Clearly the rate at which expansion can proceed will depend on how quickly new benefactions come in, and it is eminently desirable that the College should grow to its projected size of five to six hundred students without undue delay. Not only is it important that a well balanced range of courses should be offered, but from a purely economic standpoint the aim must be to ensure that facilities such as libraries, laboratories and refectories are optimally utilized.

As the first campus comes into full operation negotiations are 
being finalized for the acquisition of a second campus in town, which will house initially the Language Centre, the rapidly expanding Law School and a new Law Library. Eventually both these and future physical developments will have been completed and the pioneering days will be over; but the University College at Buckingham will continue to provide a unique environment in which to study and to teach. 


\title{
SOME NEW COBBETTIANA
}

\author{
BY JOHN W. OSBORNE
}

\section{T}

HE outstanding Cobbett collection of the Rutgers University Library has recently been fortified by some letters written by Cobbett as well as a few miscellaneous writings relating to the Rural Rider. ${ }^{1}$ The latter mainly concern efforts to secure funds for a monument to Cobbett after his death in June, I 835 .

The letters written by Cobbett are more interesting. Most of them were sent to John Fielden, member of parliament from Oldham and Cobbett's partner in representing that Lancashire industrial town in the House of Commons. None of the letters were dated earlier than June, I 832 and they reveal something of Cobbett's activities during the last few years of his life.

Cobbett was always brisk in a letter. He was never fond of circumlocution or verbosity and, like his articles in the Political Register, he made his point effectively in correspondence. One letter from Dublin written in September, 1834 describes the misery in Ireland which Cobbett saw at first hand during a visit. Another, written in July of the same year, asked Fielden for a loan of $\mathfrak{E}_{1} 50$ for "housekeeping expenses"- the nearest this collection of Cobbett's correspondence gets to his unhappy family situation during the last few years of his life. Cobbett scholars eagerly await each new discovery of papers relevant to Cobbett's life and career for information on this subject for, alas, it is clear that some previous correspondence which shed light on the situation has been destroyed.

Perhaps the most interesting letters to Fielden are those which refer to Cobbett's health. For several years prior to his death, Cobbett suffered from hoarseness and inflammation in his throat which was either caused or aggravated by the unhealthy House of Commons chamber where he sat. Now we find him writing in April, I 834 that "My cough goes on in its old way" and in the following month he told Fielden that he expected to return to the House of Commons on May 25 if his health permitted. ${ }^{2}$ But ill or not, Cobbett

\footnotetext{
${ }^{1}$ For a succinct statement of Cobbett's life and significance, see John W. Osborne's article, "William Cobbett" in the latest (I5th edition) of the Encyclopedia Britannica.

${ }^{2}$ On May 26, 1834 Cobbett did speak in parliament on the subject of the poor law, Hansard, 3rd Series. Vol. 23, cols. I3 I 9-1320.
} 
was always the optimist and in the same letter that began with a complaint about his cough, he claimed that "The Revolution has begun. . . . That 'Great Change,' which you anticipated is certainly at hand!" Still, the frequent references to bad health in those letters allows us to appreciate Cobbett's courage in making his Irish tour late in 1834 (despite its depressing revelations, the tour acted as a tonic to Cobbett's health). The letters also help to reduce the suspicion that Cobbett's frequent absences from parliament in that year were due to the blows to his vanity which his lack of ability to influence affairs in parliament inflicted.

Not all of Cobbett's letters were addressed to Fielden. One was sent to Lord Duncannon (John William Ponsonby), Home Secretary in Lord Melbourne's Whig government pleading for some Oldham men who were sentenced to transportation. But perhaps the most characteristic of all was a note to Fielden from Cobbett's London headquarters at Bolt-Court. The letter has no date and was obviously written in haste and irritation. It says, "The damned Italian villains were noising in this court, when I was going to bed last night; instead of the voice of the Nightingales and blackbirds and wood-pidgeons, which has accompanied my couchee for a month past! I wish every musician in the world was strangled."

Finally, there is a letter from William Cobbett Junior to Fielden dated October 28, I 835-over four months after Cobbett's deathasking the humanitarian Lancashire manufacturer for a $£_{5} 0$ loan to pay off a debt and to enable the Political Register to carry on. Controversial in life, Cobbett was also a source of friction after he died, for his son's bitter letter claims that Cobbett's friends who were trying to raise a monument to him had somehow held back money from the estate. This is all very curious, for William Cobbett Junior was a barrister and of course was not only Cobbett's executor but was himself well versed in the law. In any event, the Political Register did not long outlive the man who had been its heart and soul for over thirty years. 